5. nodala

\title{
Formatīvās vērtēšanas lomas pastiprināšanās, īstenojot mācīšanos iedzilinoties
}

Līga Čakāne

Domājot par izglītības mērḳiem 21. gadsimtā, vienlaikus jādomā, kā palīdzēt jauniešiem tos sasniegt. Šajā kontekstā aktuāla ir vērtēšana, kas atbalsta, regulē, sekmē mācīšanos - formatīvā vērtēšana un pašregulācija, skolēnu pašnovērtēšanas prasmju pilnveidošana.

\section{Kas ir formatīvā vērtēšana}

Vērtēšanas primārajam mērḳim jābūt: dot nepieciešamo informāciju, lai varētu uzlabot mācīšanu un mācīšanos, kas atbilst formatīvajai vērtēšanai - vērtēšanai, lai mācītos (assessment for learning). Tā nav jauna ideja vai pieeja. Literatūrā formatīvās vērtēšanas nozīmīgums un tās īstenošanas pieredze ir daudz aprakstīta. Zinātnieki raksturo formatīvās vērtēšanas būtību: iegūt pierādijjumus par skolēna sniegumu, tos interpretēt un izmantot, lai pieņemtu lēmumu par turpmākajiem mācību procesa soḷiem, lai tie būtu piemērotāki, pamatotāki. Tas nebūtu iespējams bez vērtējošās darbības (Black, \& Wiliam, 1998a, 1998b, 2009; Black, 2004).

Terminu formatīvs, to attiecinot uz vērtēšanu, pirmo reizi lietoja 1967. gadā (Scriven, 1967). Lielbritānijā 1998. gadā veiktais pētījums apliecināja, ka profesionāli īstenota formatīvā vērtēšana uzlabo skolēnu sniegumu (summatīvajā vērtēšanā) par 30\% (Black et al., 2002).

Pēdējo 10-15 gadu laikā priekšstati par formativo vērtēšanu, tās lomu un ìstenošanu pasaulē ir strauji paplašinājušies. Ir veikti apjomīgi pieejamo avotu 
analīzes apkopojumi, piemēram, projektā $\operatorname{ASSISTME}^{1}$ (Bernholt, Ronnebeck, Ropohl, Koller, \& Parchmann, 2013).

Grants Vigins uzsver, ka nepieciešams pārskatīt, kādiem mērḳiem izmantojam vērtēěanu vispār, aicinot uz vērtēšanu raudzīties kā uz līdzekli, lai uzlabotu mācišanos, nevis tikai "auditēt faktu uzkrāšanu" un aizstāt jēdzienu "vērtēšana" ar jēdzienu "atgriezeniskā saite". Viṇš rosina domāt par vērtēšanu kā par informāciju, kas nepieciešama, lai uzlabotu sniegumu. Vigins aicina atgriezties pie vērtēšanas primārā mērķa - palīdzēt skolēniem labāk mācīties un skolotājiem labāk mācīt (Wiggins, 2006).

Vigins (2006) iesaka daudz lielākā mērā izmantot tā saukto autentisko vērtēšanu (authentic assessment) jeb tādu pieeju vērtēšanai, kas prasa skolēniem demonstrēt sniegumu un radìt produktus, kas līdzinās uzdevumiem un situācijām, ar kuriem viṇi saskarsies reālajā dzīvē ar atbilstošām prasībām, iespējām un ierobežojumiem. Autentiska vērtēšana, viņaprāt, nozīmē tādu pieeju vērtēšanai, kurā tiek vērtēta skolēnu spēja "rīkoties", izmantojot attiecīgās jomas prasmes kontekstā, lai nostiprinātu viņu spēju tās efektīvi pārnest jeb vispārināt. Viginsa aicinājumu tāpèc varētu attiecināt arī uz mācīšanās iedziḷinoties pieeju mācišanai.

Vigins ir pārliecināts, ka skolēniem ir tiesības uz viņiem noderīgāku un draudzīgāku vērtēšanas sistēmu, jo skolēni ir pelnījuši saņemt vairāk atgriezenisko saiti un iespējas to izmantot. Kad vērtēšana palīdz pareizi fokusēt mācišanu šādā veidā, skolēna pašnovērtējums un spēja pašiem uzlabot savu darbu (self-adjustment) kḹst par kritiski nozīmīgu mācǐšanas un mācī̌sanās procesa daļu (Wiggins, 2006). Viginsa redzējums par vērtēšanu, izvēloties autentiskus uzdevumus, ar kuru palīdzību pakāpeniski attīstìt skolēnu prasmes, īpaši akcentē nepieciešamību uztvert vērtēšanu kā sistēmu un daḷu no mācišanas un mācīšanās procesu, nevis lēmumu par vienas vai otras metodes vai instrumenta izvēli.

Vērtēšanas eksperti (Brownlie, Feniak, \& Schnellert, 2006; Pollard, Anderson, Maddock, Swaffield, Warin, \& Warwick, 2008) lieto arī terminus vērtēšana, lai mācītos (assessment for learning), un vērtēšana kā mācišanās (assessment as learning). Lai notiktu vērtēšana kā mācǐšanās, būtiskākais aspekts ir skolotāja dota aprakstošā atgriezeniskā saite skolēnam par viņa mācišanos, iesaistot skolēnu savu rezultātu analīzē, turpmāko mācīšanās mērķu definēšanā.

Tikai tad, ja skolotājs veic šādas darbības, viņš īsteno vērtēšanu, lai mācītos (Wiliam, \& Thompson, 2007):

- skaidro mācišsanās mērķus un snieguma kritērijus, panāk skolēnu izpratni par tiem,

Assess Inquiry in Science, Technology and Mathematics Education, 8 dalibvalstu kopprojekts, FP7 atbalsts. 
- veido efektīvas sarunas klasē, izmanto uzdevumus un aktivitātes, kas dod datus, faktus, pierādījumus par mācīšanos,

- nodrošina tādu atgriezenisko saiti, kas palīdz skolēniem virzìties uz priekšu,

- aktivizē skolēnu sadarbību mācoties un dodot savstarpēju atgriezenisko saiti, lai viņi palīdzētu cits citam,

- veicina skolēnu metakognīciju, motivāciju, pašvērtējumu, atbildīgumu par savu mācišanos.

Formatīvā vērtēšana prasa abu iesaistìto pušu - gan skolotāju, gan skolēnu ieinteresētību, aktīvu, mērkstiecīgu darbību. Skolēniem jābūt skaidrai formatīiās vērtēšanas būtỉbai - ka tā domāta, lai sniegtu viṇam atbalstu, ka tā nav ne atalgojums, ne sods (Kaftan, Buck, \& Haack, 2006). Citi uzsver, ka mācī̌anās būs efektīva, ja formatīva vērtēšana ietvers atgriezenisko saiti no skolēna uz skolotāju, atgriezenisko saiti no skolotāja uz skolēnu un informācijas apmaiņu starp skolēniem (Hodgen, \& William, 2006). Tieši skolotāja profesionāli īstenotai formatīvajai vērtēšanai ir liela motivējoša ietekme. Tiek uzsvērts, ka motivē vai demotivē veids, kādā skolēnam tiek dota atgriezeniskā saite (Reece, \& Walker, 2007).

Tiek aktualizēta nepieciešamība mainīt mācību vidi no kritizējošas (tādas, kur valda konkurence, svarīgi formālie rezultāti, notiek sociāla salīizināšana, skolēnu dalīšana grupās pēc spējām, mācǐšanā un vērtēšanā uzsvars uz pareizām atbildēm, ne tik daudz uz rūpēm par saprašanu) uz motivējošu, iesaistošu (kur dominē centieni, kam seko uzlabojumi, uzsvars uz ieguldīto darbu, pilnveidošanos, jauktu spēju grupām, skolēnu kḷūdu cieṇpilnu pieņemšanu, jo tās ir mācīšanās neatṇemama sastāvdaḷa) (Maday, 2008²). Uz skolēna mācišanos orientēta vide, mācǐšanās kā aktīvs zināšanu, prasmju un attieksmju veidošanās process, sadarbība mācoties, mācišanās kā pašregulējošs process, kas ietver plānošanu, vadīšanu, refleksiju, vistiešākajā veidā ir saistīts ar formatīvās vērtēšanas īstenošanu (De Corte, 2000).

Formatīvo vērtēšanu mācību stundā (Harlen, 2013) raksturo:

- skolēnu iesaistišana, gan komunicējot stundas mērķus, gan veidojot vienotu izpratni par snieguma vērtēšanas kritērijiem,

- procesa cikliskums - skolēna darbība, ar mērķa sasniegšanu saistītu pierādījumu iegūšana, lēmums par nepieciešamajiem nākamajiem soḷiem, lēmums par to, kā tos veikt, un atbilstošas skolēna darbības.

2 Maday, T. (2008). Stuck in the Middle. Strategies to Engage Middle-Level Learners. The Center for Comprehensive School Reform and Improvement. Learning Point Associates. 
Laba formatīvā vērtēšana (Nicol, \& Draper, 2008):

- palīdz skaidrāk saprast, kāds ir labs sniegums (mērḳi, kritēriji), dod pieredzi saistīt domas ar mērķiem un kritērijiem pirms uzdevuma, tā veikšanas laikā un pēc veikšanas,

- sekmē ieguldīt laiku un pūles mācību uzdevumu veikšanā, veicina regulāru mācīšanos,

- dod augstas kvalitātes atgriezenisko informāciju, kas palīdz skolēniem pašiem uzlabot sniegumu,

- sniedz pieredzi izmantot atgriezenisko saiti, lai samazinātu plaisu starp esošo un vēlamo izpildījumu,

- pārliecina, ka vērtēšana pozitīvi ietekmē mācīšanos,

- veicina sadarbību un sarunas par mācīšanos (skolēns - skolotājs, starp skolēniem),

- rosina pilnveidot pašnovērtējuma un refleksijas prasmes,

- dod skolēnam izvēles iespējas par tematu, metodēm, kritērijiem, laiku vērtēšanai, iesaista skolēnus lēmumu pieņemšanā par vērtēšanu,

- atbalsta mācīšanos sadarbojoties,

- veicina pozitīvu motivāciju, pašapziṇu,

- dod skolotājam informāciju, ko var izmantot, lai pilnveidotu mācīšanu.

\section{Formatīvās vērtēšanas īstenošana}

Literatūrā pieejami formatīvās vērtēšanas konkrētu metožu, paṇēmienu un instrumentu apraksti, taču jāuzsver būtiskākais - formatīvā vērtēšana ir integrēta mācǐšanas un mācīšanās procesā. Tā ir nepārtraukta, tā panāk aktīvu skolēnu iesaisti savstarpējā un pašnovērtējumā, ietver atgriezenisko saiti ar ieteikumiem, kā uzlabot mācīšanos, fokusējoties tieši uz procesu, saistīta ar mācī̌sanās mērḳu precīzu definēšanu, kas palīdz mācīšanos labāk pārraudzīt (Looney, 2011³). Skolotājs nepārtraukti monitorē savu skolēnu progresu, izmantojot efektīvu jautāšanu, sarunas stundā, atsevišksu skolēnu intervēšanu un vērojumus, skolēnu pierakstus, piezīmes, skolēnu atbildes elektroniskā formā, rakstveida uzdevumu risinājumus un citas metodes. Pieejams plašs paṇēmienu klāsts, ko skolotāji var iekḷaut savā praksē (Black, \& Wiliam, 1998; Keeley, \& Tobey, 2011). Izvērtējot konkrētā paṇēmiena izmantošanu, jāṇem vērā, ka dažs no tiem fokusējas uz to, kā skolotājs var iegūt datus par skolēna mācīšanos, cits uz to, kā dot atgriezenisko saiti skolēnam, vēl citi paredz skolēnu savstarpēju vērtējumu, akcentē skolēna pašrefleksiju utt.

3 Looney, J. W. (2011). Integrating Formative and Summative Assessment: Progress Toward a Seamless Sustem? OECD Education Working Papers, No. 58. 
Formatīvā vērtēšana var būt vairāk vai mazāk formāla/neformāla. Tas atkarīgs gan no vērtēšanas procesā iegūto datu dabas un kvalitātes, gan no atgriezeniskās saites. Tā var būt īpaši plānota vai interaktīva, uz situāciju reageējoša (Shavelson Young, Ayala, Brandon, Furtak, Ruiz-Primo, \& Yin, 2008).

Detalizēti katru no formatīvās vērtēšanas paṇēmieniem raksturojuši pētnieki, vērtēšanas eksperti, piemēram, tūlītēju vērtēšanu brīdī, kad tas vajadzīgs (on the fly) (Ruiz-Primo, \& Furtak, 2006), skolotāja rakstiskus komentārus, pašnovērtējumu un savstarpējo vērtēšanu (Black, \& Harrison 2004).

Veicot formatīivo vērtěšanu, tāpat kā summatīvās vērtēšanas gadījumā jābūt skaidriem vērtēěanas kritērijiem, jo tas pilnībā nosaka, kādi skolēna snieguma aspekti tiks izvērtēti un kādus secinājumus izdarīsim. Snieguma kritēriju un to lìmen,u apraksti, mācišanās progresa apraksti ir tie instrumenti, kas skolotajam un pašiem skolēniem mācišanās procesā palīdz konstatēt esošo situāciju un plānot turpmākās darbības, lai uzlabotu sniegumu.

\section{Atgriezeniskās saites kvalitāte}

Formatīvās vērtēšanas būtiska daḷa ir atgriezeniskā saite, kas nosaka formatīiās vērtēšanas ietekmi uz mācǐšanos. Šì ietekme ir pozitīvi nozīmīga, ja atgriezeniskā saite dod noderīgu, izmantojamu informāciju, lai varētu mācī̌̌anos uzlabot.

Vērtēt, lai mācītos, nozīmē saprast, cik tālu skolēns ir ticis mācišanās procesā; saprast, kur jānokḷūst; izdomāt, kā tur nokḷūt. Tātad formatīvajai vērtēšanai jāsniedz atbildes uz jautājumiem: kas jāiemācās? kas izdodas, kas vēl ne? ko darīt turpmāk? (feed up, feed back, feed forward). Kā redzams, formatīvā vērtēšana nenotiek procesa beigās, faktiski tā sākas ar mērķu un snieguma kritēriju komunicēšanu (Wiliam, 2008; Hattie, \& Timperley, 2007; Nicol, \& Draper, 2008).

Lai uzlabotu turpmāko mācišsanos, atbildes nepieciešamas skolēnam par savu darbību un skolotajam - par viņa skolēniem. Svarīgi, lai atbildes uz šiem jautājumiem būtu pamatotas, datos un faktos balstītas. Citiem vārdiem sakot jāplāno, kā skolotājs un kā skolēni iegūs atbildes uz iepriekš minētajiem jautājumiem (skat. 1. tabulu). 
1. tabula. Jautājumu piemēri atgriezeniskās saites saṇemšanai un tās plānošanai

\begin{tabular}{ll}
\hline $\begin{array}{c}\text { Jautājumi, uz kuriem tiek saṇemtas } \\
\text { atbildes, ja notiek formatīvā vērtēšana }\end{array}$ & \multicolumn{1}{c}{$\begin{array}{c}\text { Jautājumi, kuri ir būtiski, plānojot } \\
\text { atgriezeniskās saites došanu }\end{array}$} \\
\hline Kas jāiemācās? & Kā skolotājs iegūst informāciju par to, kā veicas? \\
Kā veicas? & Kā skolēni uzzina, saprot, saṇem atbildes uz \\
Ko zinu, protu, cik labi? & jautājumiem par savu mācīšnos? \\
Ko vēl nezinu, neprotu? Kāpēc? & Kā tiek mācīta atgriezeniskās saites izmantošana? \\
Ko un kā darīt turpmāk? & Kā panākt skolēna iesaistǐšanos, jo atgriezeniskā \\
& saite ir mijiedarbīgs process. \\
\hline
\end{tabular}

Atgriezeniskā saite tiek īstenota starp abām mācību procesā iesaistītajām pusēm - skolotāju un skolēnu. Skolēns, kurš sapratis atgriezeniskās saites nozīmi, ir ieinteresēts, lai skolotājs iegūtu pēc iespējas precīzu informāciju par to, kā viņam veicas, kas izdodas un kas pagaidām ne (skolēns dod atgriezenisko saiti skolotājam). Skolotājs, saṇemot šo informāciju, plāno savu turpmāko darbību (kas un kā jāmāca), dod izmantojamu atgriezenisko saiti skolēnam par to, kas viņam jādara turpmāk un paredz iespēju skolēnam saṇemto atgriezeniskās saites informāciju tūlìt izmantot.

Atgriezeniskā saite izmantojama 4 dimensijās:

- uzdevuma dimensija - cik labi ir saprasts, izpildīts konkrētais uzdevums,

- procesa dimensija - kas ir nepieciešams, kas jādara, lai saprastu, izpildītu uzdevumu,

- pašregulācijas dimensija - kā skolēns var labāk sevi kontrolēt, virzìt un regulèt savu darbỉbu,

- personas dimensija - skolēna kā personas vērtējums (Hattie, \& Timperley, 2007).

Procesa un pašregulācijas dimensijas ir ḷoti būtiskas, domājot par mācīšanās uzlabošanu. Skolotāju praksē vērtējums bieži vien paliek uzdevuma līmenī, taču šāda informācija vairumam skolēnu nav pietiekama. Dodot skolēnam atgriezenisko saiti un ieteikumus par to, kā uzlabojams pats mācǐšanās process un ko skolēns var darīt, lai turpmāk pats varētu labāk vadìt savu mācišsanos, skolotājs ne tikai tieši palīdz skolēnam konkrētajā situācijā, bet arī dod iespēju veidot pieredzi par to, kam mācoties jāpievērš uzmanība. Tas var palīdzēt skolēnam prasìt un pieñemt viņam noderīgu atgriezenisko saiti un māca tādu dot citiem skolēniem. Savstarpējas vērtēšanas nosacijums: klasē ir pozitīva, uz mācišanos vērsta gaisotne, savstarpējas uzticēšanās attiecības starp skolēniem, kas arī kḷūst par vienu no skolotāja darbības virzieniem.

Dot un pieņemt atgriezenisko saiti ir jāmācās, un ir pieejami labi piemēri, kā skolotāji Latvijā to dara. 1. attēlā redzams, kā tas tiek mācīts sākumskolas 


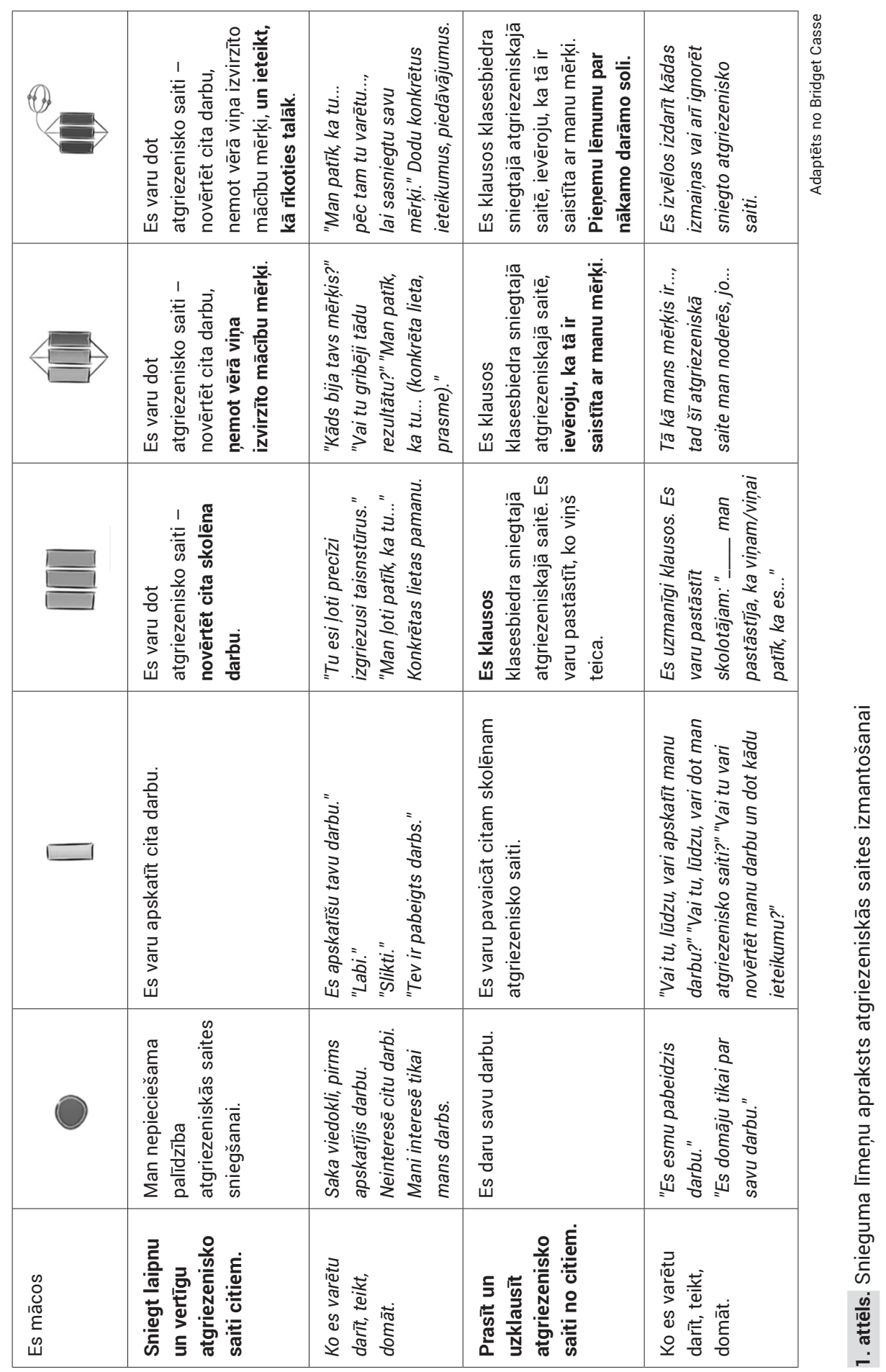


$\mathrm{X}$ skolēniem, izmantojot snieguma līmeṇu aprakstu (rubriku), kas adaptēta no Jaunzēlandes skolotājas Bridget Casse.

Viens no efektīvas atgriezeniskās saites nosacījumiem - tai jābūt maksimāli ātrai laikā. Šajā ziṇā papildu iespējas dod IT rīku izmantošana formatīvajā vērtēšanā. Tas ir būtiski, domājot arī par iespējami personalizētu atgriezenisko saiti klasē ar lielu skolēnu skaitu.

Runājot par formatīvās vērtēšanas ietekmi uz mācišanos, svarīgs aspekts ir atgriezeniskās saites izmantojamība (ne katra atgriezeniska saite ir noderīga skolēnam) un iespējas to tūlīt izmantot, lai sniegumu uzlabotu. Atgriezeniskās saites izmantojamību nosaka tas, vai skolēns saprot viņam dotās informācijas saturu, jēgu. Savukārt pat kvalitatīva atgriezeniskā saite pati par sevi nav efektīva, ja tai neseko skolēna darbība, kurā viņš iegūto informāciju izmanto, ja neturpinās mācǐšanās process (Halperna, 2014).

\section{Formatīvā vērtēšana un pašregulācija}

Skolēna prasme izmantot formatīvajā vērtēšanā iegūto informāciju ir cieši saistìta ar skolēna prasmi vadīt savu mācīšanos. Tieši noderīga atgriezeniskā saite un skolotāja veicināta atgriezeniskās saites izmantošana savas turpmākās darbības plānošanā, objektīvu mērḳu izvirzī̌sanā ir pašvadītas mācīšanās elementi.

Pašnovērtējums nenozīmē fiksēšanu, vai un cik pareizas atbildes ir bijušas, veicot uzdevumu. Skolēns vada savu mācišanos, ja viņš saista savu šì brīža sniegumu ar plānotajiem mācīšanās mērḳiem un atgriezenisko saiti ar to, kā tikt tuvāk mērḳim. Pirmais solis, ko skolotājs var veikt, ir dot skolēnam šādu pieredzi stundās - lai skolēns redz, kā skolotājs definē mācišsanās mērḳus un snieguma kritērijus, vērtē sniegumu atbilstoši šiem kritērijiem un palīdz konstatēt, kādas turpmākās darbības nepieciešamas, korigee plānus, formulē jaunus mērḳus.

Mēginot panākt objektīvāku snieguma vērtēšanu, vienlaikus arvien vairāk sava darba novērtēšanā tiek iesaistīti paši skolēni (Stiggins, Arter, Chappuis, \& Chappius, 2004). Prasmīgi izmantojot snieguma vērtēšanu, skolēniem ir iespēja skaidrāk saredzēt sava snieguma līmeņus un izprast kvalitatīva darba kritērijus. Faktiski viens no formatīvās vērtēšanas nolūkiem ir padarìt skolēnus par efektīviem pašnovērtētājiem, kuri spēj savā sniegumā saskatīt gan stiprās puses, gan trūkumus un plānot savu turpmāko darbību. Ir būtiski, lai skolēni praktizējas vērtēšanā, redzot gan kvalitatīva, gan mazāk kvalitatīva snieguma piemērus, izmanto gan dotus, gan paša izstrādātus snieguma kritērijus.

Savas mācī̌sanās vadīšanai noderīgi rìki ir snieguma līmeņu apraksti - rubrikas. Tiek norādīts, ka rubrikas palīdz skolēniem saprast pazīmes, kas raksturo labu darbu, dod skaidrību par mērḳi un snieguma kritērijiem. Tādējādi rubrikas 
palīdz skolotājiem mācìt, saskaņot māciššnu ar vērtēšanu un palīdz skolēniem mācīties. Skolēni saṇem rubriku temata sākumā, veic uzdevumus, saṇem atgriezenisko saiti atbilstoši kritērijiem, veic nākamo uzdevumu un turpina vingrināties, līdz noslēgumā saṇem vērtējumu (atzīmi), balstoties uz šo pašu rubriku. Šāda mācišanās ir daudz iedarbīgāka nekā uzdevumu sērija ar saistītiem, bet atšḳirīgiem kritērijiem (Brookhart, 2013).

Liels potenciāls mācību kvalitātes uzlabošanā ir mācišanās progresa aprakstiem - progresējoša snieguma rubrikām (learning progression), kurās līmeṇu apraksti nevis vienkārši diferencē vājāku vai pārliecinošāku sniegumu, bet gan raksturo tipisku secību, kādā konkrētā prasme attīstās (skat. 1. attēlu). Šādas rubrikas varētu būt īpaši noderīgas gan skolēniem, gan skolotājiem, lai viṇi precīzāk varētu noteikt, kur viṇi "atrodas" ceḷā uz mērḳi un kāds atbalsts viņiem nepieciešams. Šādas rubrikas palīdzētu pievērst uzmanību arī domāšanas modeliem par attiecīgo jautājumu, ne tikai gatavām atbildēm. Formatīvajā vērtēšanā izmantojami dažādi paņēmieni un instrumenti. Tie, kas atsedz, palīdz saprast domāšanu, skolēnam varētu dot ìpaši lielu labumu.

\section{Formatīvā vērtēšana un skolotāja prasmes un uzskati}

Ar ESF atbalstu Valsts izglîtības satura centra îstenotajos projektos "Mācību satura izstrāde un skolotāju tālākizglīîiba dabaszinātṇu, matemātikas un tehnologiju priekšmetos" un "Dabaszinātnes un matemātika" vēroto stundu dati saistībā ar formatīvo vērtěšanu uzrāda pozitīvas tendences: vērtēšana notiek daudzveidīgi, skolēniem tiek skaidroti mācīšanās mērḳi un snieguma kritēriji, vērojama efektīva sadarbība, vērtējums tiek izmantots turpmākās mācišanās plānošanā, tiek attīstītas skolēnu pašnovērtēšanas prasmes. Tajā pašā laikā ir daudz nepilnību, veicot formatīvo vērtēšanu: stundās redzama formatīiās vērtēšanas būtības neizpratne, neskaidri stundas mērḳi, pilnvērtīga mācību dialoga trūkums, vērtējot akcents tiek likts uz reproduktīva līmeņa prasmju vērtēšanu, tiek izdarīti nepārliecinoši secinājumi.

Latvijas Universitātes Starpnozaru izglìtības inovācijas centra (LU SIIC) veiktie stundu vērojumi rāda atsevišķas veiksmīgas aktivitātes mācību stundās, kad skolotāji māca skolēnus dot un pieṇemt atgriezenisko saiti par mācīšanos. Piemēram, epizode no matemātikas stundā 10. klasei skolā A, kur skolēni veica pētỉjumu par šaurā leṇķa trigonometrisko funkciju vērtỉbu saskatāmību vienības riṇ̂īi.

Skolotāja: "Iedošu instrumentu, kas var palīdzēt katram saprast, kur viņš ir cel̦ā uz labu problēmrisinātāju. Lūdzu, iezīmējiet katrs vietu, kur tu domā, ka esi šobrīd. Un uzrakstiet apakšà - kāpēc tu domā, ka tu tur esi, kā tu to zini. Tas 
paliks pie jums. Šajā rubrikā jūs varat arī redzēt, kā tikt tālāk uz nākamo soli.” Skolēni saṇem rubriku:

2. tabula. Progresējoša snieguma līmen,u apraksts problēmas risināšanai

\begin{tabular}{|c|c|c|c|c|}
\hline$\rightarrow$ & $\rightarrow$ & $\rightarrow$ & $\rightarrow$ & $\rightarrow$ \\
\hline $\begin{array}{c}\text { Atrisinu } \\
\text { problēmu, } \\
\text { izmantojot } \\
\text { dotu plānu, } \\
\text { bet neprotu } \\
\text { pārliecināties, } \\
\text { vai risinājums ir } \\
\text { derīgs. }\end{array}$ & $\begin{array}{c}\text { Atrisinu } \\
\text { problēmu, } \\
\text { izmantojot dotu } \\
\text { plānu, protu } \\
\text { pārliecināties, } \\
\text { vai risinājums ir } \\
\text { derīgs. }\end{array}$ & $\begin{array}{l}\text { Atrisinu problēmu } \\
\text { pats, bet neprotu } \\
\text { pārliecināties, } \\
\text { vai risinājums ir } \\
\text { derīgs. }\end{array}$ & $\begin{array}{c}\text { Atrisinu } \\
\text { problēmu } \\
\text { pats un protu } \\
\text { pārliecināties, } \\
\text { vai risinājums ir } \\
\text { derīgs. }\end{array}$ & $\begin{array}{c}\text { Atrisinu problēmu } \\
\text { pats, varu to } \\
\text { izdarīt vairākos } \\
\text { veidos un protu } \\
\text { pārliecināties, } \\
\text { vai risinājumi ir } \\
\text { derīgi. }\end{array}$ \\
\hline
\end{tabular}

LU SIIC veiktajos pētījumos (France, Namsone, \& Čakāne, 2015), vērojot mācību stundas 10 skolās laika periodā no 2013. līdz 2015. gadam (kopumā iegūstot un analizējot datus par 368 stundām 1.-12. klašu dažādos mācību priekšmetos), analizēta arī formatīvas vērtēšanās izmantošana stundās. Dati rāda, ka tikai $49 \%$ visu pētījumā vēroto stundu skolēniem stundā ir skaidrs plānotais sasniedzamais rezultāts, 54\% gadījumu skolotājs konstatē stundā sasniegto. Vērojama tendence skolotājam konstatēt, vai stundā sasniegts plānotais rezultāts, bet tas nepietiekami tiek izmantots tūlītējai atgriezeniskās saites došanai skolēniem. Stundās pēc konkrētu uzdevumu veikšanas skolēniem ir iespēja pārliecināties, vai viṇu iegūtās atbildes ir pareizas, bet viṇi nesaṇem skolotāja konstruktīvus ieteikumus par to, kas un kā būtu jādara, lai mācīšanās rezultāts būtu labāks. Stundas beigās veiktais pašnovērtējums bieži ir vairāk emocionālā līmenī, trūkst skaidru kritēriju, lai pārliecinātos par rezultāta un mācīšanās procesa kvalitāti.

Arī citur pasaulē profesionāli īstenota formatīvā vērtēšana nebūt vēl nav ikviena skolotāja ikdienas prakse. Analizējot šḳēršlus formatīvas vērtēšanas ìstenošanā, pētnieki uzsver, ka traucē skolotāju dziļie pedagoǵiskie uzskati par vērtēšanu kā skolotāja rīku un atbildību, nevis kā par iespēju iesaistīt skolēnus, veidojot konstruktīvu vērtējošu vidi (Bernholt et al., 2013). Viṇi atsaucas uz American Association for the Advancement of Science, ka vērtēšana lielākās daḷas skolotāju un skolēnu prātos tiek nošķirta no mācīšanās. Skolotāji nav droši par to, ka sabiedrība kopumā šādu vērtēšanu akceptē, un viņiem ir nepieciešams atbalsts, lai mainītu savus priekšstatus par skolotāja lomu. Projekta ASSISTME $^{4}$ pieredze kā šḳēršlıus formatīvās vērtēšanas īstenošanā uzrāda lielas

4 Assess Inquiry in Science, Technology and Mathematics Education, 8 dalibvalstu kopprojekts, FP7 atbalsts. 
klases, skolotāju grūtības, sastopot atšķirīgus skolēnus, viņu dažādās vajadzības, bažas, ka formatīva vērtēšana ir resursu un laika ietilpīga, nepietiekamā saskaņotība starp vērtēšanu klases, skolas un valsts līmenī, dažādie izglitības politikas veidotāju un skolu vadìtāju uzskati. Līdzīgi arī Latvijā - starp problēmām, kas ietekmē vērtēšanu, atzīmējama skolēna, skolotāja, skolas, vecāku dažādā izpratne un ar to saistìtās vajadzības. Skolu izstrādātajos Vērtēšanas nolikumos (kārtībās) akcentēti formālie rādītāji, stingri reglamentēts nepieciešamais vērtējumu skaits ballēs, arī valsts līmeņa dokumentos akcentēta summatīvā vērtēšana.

Par vērtēšanu tiek runāts kā par atseviškiem paņēmieniem, tehnikām, procedūrām nošķirti no citām mācǐšanas un mācǐšanās aktivitātēm (Coffey, Hammer, Levin, \& Grant (2011). Formatīvā vērtēšana pārāk maz tiek iestrādāta mācību programmās. Būtiska ir ciešāka sasaiste starp pētniekiem, politikiem, vērtēšanas ekspertiem un skolotājiem, kā arī starp pašiem skolotājiem (Shavelson et al., 2008).

Attiecībā uz skolotājam nepieciešamajām prasmēm, lai īstenotu efektīvu formatīvo vērtēšanu, specifiska ir prasme diagnosticēt (Turner, 2014). Savukārt saistībā ar formatīvo vērtēšanu jādomā nevis par to, kā skolotājam apgūt jaunas zināšanas, bet gan par ieradumu mainu (William, 2006). 2008. gada OECD $\mathrm{CERI}^{5}$ 40. gadadienas konferencē prezentācijā, runājot par vērtēšanas, lai mācìtos ieviešanas problēmām, Viljams uzsver: "Skolotāji lielāko dạ̧u no tā jau zina problēma nav zināšanu trūkums. Tas ir izpratnes trūkums par to, ko nozīmē vērtēšana, lai mācītos - tāpēc stāstīšana skolotājam, ko darìt, nestrādā." ${ }^{\prime 0}$ Šie pirms vairāk nekā 10 gadiem izteiktie secinājumi Latvijas kontekstā ir aktuāli joprojām. Jēgpilnai formatīvajai vērtēšanai nepieciešama dziḷa izpratne, pieredze un pārliecība, jo formatīvā vērtěšana nav ikdienas prakse Latvijas vidusskolās, kā savā promocijas darbā secina Anžela Jurāne-Brēmane (2018).

Vērtēšanu skolotāju praksē ietekmē skolotāju uzskati, kurus Amerikas matemātikas skolotāju padome ${ }^{6}$ piedāvā pretstatīt kā neproduktīvus un produktīvus, uzsverot, ka tie nav labi vai slikti. Produktīvi uzskati atbalsta efektīvu mācišsanu un mācǐšanos, neproduktīvi ierobežo skolēnu būtiskas praktizēšanas iespējas (skat. 3. tabulu).

5 OECD CERI. (2008). 21st Century Learning: Research, Innovation and Policy. Directions from recent OECD analyses. OECD Center for Educational Research and Innovation. Pieejams: http:// www.oecd.org/site/educeri21st/40554299.pdf (aplūkots 20.10.2017.).

6 National council of teachers of mathematics. Principlesto Actions. Ensuring MathematicalSuccess for ALL (2017). Pieejams: https://www.nctm.org/uploadedFiles/Standards_and_Positions/PtA ExecutiveSummary.pdf (aplūkots 14.02.2018.). 
3. tabula. Skolotāju uzskati par vērtēšanu

\begin{tabular}{|c|c|}
\hline Neproduktīvi uzskati & Produktīvi uzskati \\
\hline $\begin{array}{l}\text { Vērtēšana primāri ir atbildība informēt } \\
\text { skolēnus par atzīmēm. }\end{array}$ & $\begin{array}{l}\text { Vērtēšanas primārais mērḳis ir informēt par } \\
\text { mācīšanos, uzlabot mācīšanu un mācǐšanos. }\end{array}$ \\
\hline $\begin{array}{l}\text { Vērtēšana notiek, mācīšanās procesu } \\
\text { pārtraucot. }\end{array}$ & $\begin{array}{l}\text { Vērtēšana ir nepārtraukts process, kas ir } \\
\text { iestrādāts mācīšanā, lai atbalstītu skolēnu } \\
\text { mācǐšanos un veiktu korekcijas mācǐšanā. }\end{array}$ \\
\hline $\begin{array}{l}\text { Tikai testi un citi “objektīvi” rakstiski } \\
\text { pārbaudes darbi mēra matemātikas } \\
\text { zināšanas droši un precīzi. }\end{array}$ & $\begin{array}{l}\text { Matemātiskā izpratne un process var } \\
\text { tikt mērīts, lietojot dažādus vērtēšanas } \\
\text { paṇēmienus un uzdevumus. }\end{array}$ \\
\hline $\begin{array}{l}\text { Atsevišḳs vērtējums var tikt izmantots, lai } \\
\text { pieṇemtu svarīgus lēmumus par skolēniem } \\
\text { un skolotājiem. }\end{array}$ & $\begin{array}{l}\text { Nepieciešami daudzveidīgi datu avoti, lai } \\
\text { veidotu precīzu ainu par skolēnu un skolotāju } \\
\text { sniegumu. }\end{array}$ \\
\hline Vērtējums informē skolēnus. & $\begin{array}{l}\text { Vērtēšana ir process, kam jāpalīdz, lai skolēni } \\
\text { kḷūtu labāki sava darba vērtētāji, kas palīdz } \\
\text { saskatīt augstas kvalitātes darbu, kas sniedz } \\
\text { atbalstu, izmantojot iegūtos pierādījumus, lai } \\
\text { uzlabotu savu mācīšanos. }\end{array}$ \\
\hline $\begin{array}{l}\text { Mācīšanas pārtraukšana, lai pārbaudītu, } \\
\text { veiktu testus, uzlabo skolēnu sniegumu } \\
\text { augstas likmes pārbaudījumos. }\end{array}$ & $\begin{array}{l}\text { Nepārtraukta pārskatīšana, praktizēšanās } \\
\text { iekḷaušana efektīvā mācību procesā ir } \\
\text { produktīva stratēǵija, kā sagatavoties } \\
\text { pārbaudījumiem. }\end{array}$ \\
\hline
\end{tabular}

Arī Latvijas pieredze rāda, ka efektīvas formatīvās vērtēšanas iedzīvināšana saistās ar skolotāja personību. Tiek aicināts skatît vērtējošās darbības autoritārās un humānās pedagog̣ijas kontekstā. Formatīvā vērtēšanā ir humānās izglìtības paradigmas elements, to nekad pilnvērtīgi neizmantos autoritārs skolotājs. Aktuāla ir neuzticēšanās skolēnam kā godprātīgam un ieinteresētam pēc iespējas labāk mācīties (Hahele, 2006).

Viens no iemesliem, kāpēc formatīvā vērtēšana nav ierasta skolotāja ikdienas prakse un tā netiek atbilstošā veidā īstenota, ir tas, ka skolotājam pašam nav personīgas pieredzes, kā laba atgriezeniskā saite palīdz uzlabot sniegumu - viņš nav izjutis formatīvās vērtēšanas, noderīgas atgriezeniskās saites pozitīvo ietekmi gan tad, kad pats mācỉjās kā skolēns, gan attiecībā uz sevi kā darbinieku. Arī skolotājam nepieciešama profesionāla, izmantojama atgriezeniskā saite.

7 National council of teachers of mathematics. Principles to Actions. Ensuring Mathematical Successfor ALL (2017).Pieejams:https://www.nctm.org/uploadedFiles/Standards_and_Positions/ PtAExecutiveSummary.pdf (aplūkots 14.02.2018.). 


\section{Secinājumi}

Lìdz šim valsts līmeņa izglîtîbu reglamentējošos dokumentos nav nostiprināta formatīvās vērtēšanas nozīme. Izglìīibas standartos nepieciešams skaidri parādīt formatīvās vērtēšanas vietu un lomu mācību procesā, uzsverot tās nozīmīgumu gan konkrētā satura mācǐšanas aspektā, īstenojot mācǐšanos iedziḷinoties, gan kā būtisku pašvadītas mācišanās elementu.

Formatīiās vērtēšanas efektivitāte atkarīga no skolotāju prasmēm. Nepieciešams pilnveidot skolotāju izpratni par formatīvo vērtēšanu, prasmi izmantot dažādus vērtēšanas instrumentus, izmantot iegūtos datus, lai veiktu uzlabojumus gan mācišanā stundas līmenī, gan nodrošinot, ka skolēni saṇem noderīgu atgriezenisko saiti un uzlabo savu mācīšanos, mācās to vadīt.

Jāizplata labās prakses piemēri, nepieciešams sekmēt skolotāju profesionālu sadarbību, ieviešot un pārbaudot formatīiās vērtēšanas paṇēmienus, veicot savas darbības izpēti, lai iegūtu pierādījumus, kas apliecina vērtēšanas efektivitāti.

Jāturpina pētījumi par formatīvās vērtēšanas īstenošanu mācību procesā un tās ietekmi uz skolēnu sniegumu un motivāciju, lai skolu prakse vairāk balstītos pētījumu datos un būtu lielāka pārliecība par pieejas efektivitāti.

\section{IZMANTOTĀ LITERATŪRA}

Bernholt, S., Ronnebeck, S., Ropohl, M., Koller, O., \& Parchmann, I. (2013). ASSIST ME. Report on current state of the art in formative and summative assessment in IBE in STM. ASSIST-ME Report Series Number 1-2.

Black P., Broadfoot, P., Daugherty, R., Gardner J., Harlen, W., James, M., Stobart, G., \& Wiliam, D. (2002). Testing, Motivation and Learning. Nuffield Foundation and University of Cambridge.

Black P., \& William, D. (2009). Developing the theory of formative assessment. Educational Assesment, Evaluation and Accountabillity, 21(1), p. 53.

Black, P. (2004). The Nature and Value of Formative Assessment for Learning. London.

Black, P., \& Harrison, C. (2004). Science Inside the Black Box. London: NferNelson.

Black, P., \& Wiliam, D. (1998a). Inside the black box: Raising standards through classroom assessment. Phi Delta Kappan, 80(2), pp. 139-148.

Black, P., \& Wiliam, D. (1998b). Assessment and Classroom Learning. A review of 25 years of World Wide Research on Formative Assessment. London.

Brookhart, S. M. (2013). How to Create and Use Rubrics for Formative Assessment and Grading, Chapter 1. Pieejams: http://www.ascd.org/publications/books/112001/chapters/ What-Are-Rubrics-and-Why-Are-They-Important\%C2\%A2.aspx (aplūkots 14.02.2018.).

Brownlie, F., Feniak, C., \& Schnellert, L. (2006). Student Diversity (2 ${ }^{\text {nd }}$ ed.) Markham, ON: Pembroke Publishers.

Coffey, J. E., Hammer, D., Levin, D. M., \& Grant, T. (2011). The missing disciplinary substance of formative assessment. Journal of research in science teaching 48(10), pp. 1109-1136. 
De Corte, E. (2004). High-powered learning communities: a european perspective. CIP\&T, University of Leuven, Belgium.Council's Research Programme on Teaching and Learning, Leicester, England, November 9-10.

France, I., Namsone, D., \& Cakane, L. (2015). What Research Shows about Mathematics Teachers' Learning Needs: Experience from Latvia. In SOCIETY, INTEGRATION, EDUCATION (Vol. 2, pp. 45-55). http://dx.doi.org/10.17770/sie2015vol2.457

Hahele, R. (2006). Pašnovērtējums mācību procesā. Rīga: RaKa.

Halpern, D. F. (2014). Thought and Knowledge: An Introduction to Critical Thinking (5 $5^{\text {th }}$ ed). NY: Psychology Press.

Harlen, W. (2013). Assessment and inquiry-based science education: issues in policy and practice. Global Network od Science Academies (IAP) Science Education Programme (SEP).

Hattie, J., \& Timperley, H. (2007). The Power of Feedback. Review of Educational Research, 77(1), pp. 81-112.

Hodgen, J., \& Wiliam, D. (2006). Mathematics inside the Black Box. Assessment for learning in the mathematics classroom. Department of Education \& Professional Studies King's College London. NferNelson.

Jurāne-Brēmane, A. (2018). Formatīvā vērtēšana studiju procesā. Promocijas darbs doktora zinātniskā grāda iegūšanai pedagoǵijā. Latvijas Universitāte.

Kaftan, J. M., Buck, \& G. A., Haack, A. (2006). Using Formative Assessments to Instruction and Promote Learning. Middle School Journal. National Middle School Individualize Association.

Keeley, P., \& Tobey, C. R. (2011). Mathematics Formative Assessment. 75 Practical Strategies for Linking Assessment, Instruction and Learning. - NCTM, Corwin.

Nicol, D., \& Draper, S. (2008). Redesigning written feedback to students when class sizes are large. Paper presented at the Improving University Teachers Conference, Glasgow, UK.

Pollard, A., Anderson, J., Maddock, M., Swaffield, S., Warin, J., \& Warwick, P. (2008). Reflective teaching: evidence-informed professional practice. ( $3^{\text {rd }}$ ed.) London: Continuum International Publishing Group.

Reece, I., \& Walker, S. (2007). Teaching, training \& learning. A.practical guide. 6 Rev Ed. Business Education Publishers Ltd (United Kingdom).

Ruiz-Primo, M. A., \& Furtak, E. M. (2006). Informal formative assessment and scientific inquiry: Exploring teachers' practices and student learning. Educational Assessment, 11(3-4), pp. 237-263.

Scriven, M. (1967). The methodology of evaluation. In Perspectives on curriculum evaluation, ed. R. Tyler, R. Gagne, and M. Scriven. AERA monograph series - curriculum evaluation Chicago: Rand McNally.

Shavelson, R. J., Young, D. B., Ayala, C. C., Brandon, P. R., Furtak, E. M., Ruiz-Primo, M. A., \& Yin, Y. (2008). On the impact of curriculum-embedded formative assessment on learning: A collaboration between curriculum and assessment developers. Applied Measurement in Education, 21(4), pp. 295-314.

Stiggins, R. J., Arter, J. A., Chappuis, J. \& Chappius, S. (2004). Classroom assessment for student learning: Doing it right - using it well. Portland, Oregon: Assessment Training Institute.

Turner, S. L. (2014). Creating an assessment-centered classroom: Five essential assessment strategies to support middle grades student learning and achievement. Middle School Journal, 45(5), pp. 3-16. 
Wiggins, G., \& McTighe, J. (2006). Understanding by Design. $2^{\text {nd }}$ ed. Association for Supervision and Curriculum Development: Alexandria, VA.

William, D. (2006). Assessment: learning communities can use it to engineer a bridge connecting teaching and learning. Journal of Staff Development, 27(1), pp. 16-20.

William, D., \& Thompson, M. (2007). Integrating assessment with instruction: what will it take to make it work? In Dwyer, C. A. (ed.). The future of assessment: shaping teaching and learning (pp. 53-82). Mahwah, NJ: Lawrence Erlbaum Associates. 